\title{
Grapevine Variety and Number of Canes Affect Dry-on-Vine (DOV) Raisin Production on an Overhead Arbor Trellis
}

\author{
Matthew W. Fidelibus
}

Citation: Fidelibus, M.W. Grapevine Variety and Number of Canes Affect Dry-on-Vine (DOV) Raisin Production on an Overhead Arbor Trellis. Horticulturae 2021, 7, 356. https://doi.org/10.3390/ horticulturae7100356

Academic Editor: Esmaeil Fallahi

Received: 3 September 2021

Accepted: 24 September 2021

Published: 2 October 2021

Publisher's Note: MDPI stays neutral with regard to jurisdictional claims in published maps and institutional affiliations.

Copyright: (C) 2021 by the author. Licensee MDPI, Basel, Switzerland. This article is an open access article distributed under the terms and conditions of the Creative Commons Attribution (CC BY) license (https:// creativecommons.org/licenses/by/ $4.0 /)$.
Department of Viticulture and Enology, University of California, Davis, CA 95616-8749, USA; mwfidelibus@ucdavis.edu

\begin{abstract}
Making raisins (dried grapes) is a laborious process and grape growers around the world are increasingly interested in adopting mechanized methods, especially dry-on-vine (DOV). The DOV method entails severing canes bearing mature fruit, causing them to DOV, after which they may be harvested by machine. The overhead arbor is an important DOV raisin trellis system, but basic agronomic performance of raisin varieties on that system are scant. Therefore, a three-year experiment was conducted to compare the performance of several raisin grape varieties (Vitis vinifera L.), on an overhead arbor trellis, for production of DOV raisins. Grapevine variety, 'DOVine', 'Fiesta', 'Selma Pete', or 'Thompson Seedless', was the main-plot factor, and number of canes, six or eight, was the sub-plot. 'Fiesta' produced the highest yields, averaging about $12.24 \mathrm{Mg} / \mathrm{ha}$ raisins. However, 'Fiesta' generally had the lowest soluble solids and among the lowest raisin grades. The later ripening of 'Fiesta' fruit delayed harvest pruning to initiate fruit drying compared to the other varieties. Therefore, its raisins did not dry sufficiently to meet industry standards. 'Selma Pete', 'DOVine', and 'Thompson Seedless' had similar yields, generally about 20\% less than 'Fiesta', but 'Selma Pete' produced fruit that were the largest in size, with the highest soluble solids, and that produced raisins of the highest grades, compared to the other varieties. Vines pruned to eight canes produced higher yields without sacrificing raisin quality. In conclusion, 'Fiesta' was notable for its high productivity, and 'Selma Pete' for its earliness and high quality, and both varieties had sufficient capacity to carry eight 15-node canes.
\end{abstract}

Keywords: canopy management; dried vine fruit; raisins; pruning; trellis

\section{Introduction}

California is a globally important source of raisins, mostly from 'Thompson Seedless' grapes (Vitis vinifera L.) [1,2]. Traditionally, California raisin growers employed manual labor crews to pick clusters of ripe grapes and place them on paper trays, between vine rows, to dry. Sometimes crews are needed again during drying to turn or roll the trays of grapes [1]. After a few weeks, labor crews pick up the trays of dried raisins and deposit them into bins. In other countries, such as Argentina, raisin grapes are traditionally dried in yards, a process that is even more laborious and costly than drying in the vineyard, as yard drying requires similar tasks as tray-drying in a vineyard, but also requires transporting fresh fruit from the vineyard to the yard [3]. Raisin producers in most countries have recognized that traditional raisin making methods are excessively laborious and costly, and that growers will eventually need to adopt alternative methods such as dry-on-vine (DOV) [1,3-5].

As currently practiced, DOV is based on fundamental concepts conceived of decades ago in Australia [6]. Essentially, canes bearing clusters of mature grapes are severed, causing the grapes to DOV, and the dried grapes are machine harvested, directly from the trellised vines [1]. Australians further developed the basic concept into an integrated system including specialized trellises that facilitate separation of the canopy into fruiting and renewal zones such that the grapes can be treated with an emulsion that hastens 
drying without damaging the leaves of renewal shoots [7]. Raisins made from grapes treated with drying emulsion are lighter colored and have a different flavor than "natural" raisins, which are sun-dried without pretreatment [1]. California producers prefer darkcolored natural raisins, so drying emulsion is not widely used. Without drying emulsion, 'Thompson Seedless', California's traditional raisin grape, generally ripens too late to adequately DOV $[1,8]$.

A lack of earlier-ripening raisin grapes inhibited the development of DOV production systems in California, and natural "Thompson-type" DOV raisins were not widely produced here until early-ripening raisin grape varieties became available, and economic incentives forced growers to consider planting them [1,4,5]. 'Fiesta' was released in 1974 as an earlier-ripening alternative to 'Thompson Seedless' for tray-drying [9]. 'DOVine' was released in 1995 and is notable for being the first seedless grape variety resulting from the hybridization of two seedless grapes using Dr. David Ramming's embryo rescue techniques [10]. It was also the first raisin grape specifically selected for DOV. 'Selma Pete' was released in 2001 as a particularly early-ripening Thompson-type raisin grape for DOV [11].

For several reasons, including later adoption of DOV, a different climate, new grape varieties, and different raisin quality needs, California's raisin industry eventually developed DOV production systems that differed from those in Australia. Californians tested several different DOV systems over the years [12], with most growers eventually settling on the open gable or overhead arbor [1]. The open gable employs a large Y-shaped trellis, similar to a table grape trellis [13]. The canopy of DOV raisin grapes on open gable trellises are generally separated into distinct fruiting and renewal zones using selective cane-pruning and shoot positioning [14]. Some growers use center-divided canopies where renewal shoots are gathered in the trellis center and supported by a foliage catch wire, whereas others use within-row alternate-bearing (WRAB), where selective pruning results in canes and spurs on opposite cordons [14]. Regardless of the canopy separation method used, the open gable's symmetrical, free-standing design provides relatively good exposure of the fruit to the sun, especially when canopy management techniques such as canopy separation and hedging are employed. Sun-exposure increases fruit temperature, thereby reducing drying time [15], and the relatively large trellis size, compared to traditional raisin trellises, increases vine capacity. As a result, open gable DOV vineyards are more productive than conventional raisin vineyards and the fruit generally dries in a timely fashion [13].

Overhead arbor systems were developed by the growers L. Simpson and G. Pitts [12]. Simpson developed a high-density overhead arbor vineyard in 1991 with head-trained and cane-pruned 'Fiesta' grapevines, whereas Pitts' system uses vines that are more widely spaced and trained to quadrilateral cordons [12]. In both systems, the vine's canopies are separated into fruiting and renewal sections by pruning the vines and tying their canes in such a way that trellis wires spanning the spaces between adjacent rows support either fruiting canes or renewal shoots (Figure 1). Cane severance, to initiate fruit drying, necessitates spur pruning the following season, so fruiting and renewal sections alternate each year.

The canopy cover in overhead arbor vineyards may exceed $80 \%$ by midsummer [16], potentially enabling yields that are higher than those of vines in an open gable vineyard. Cathline et al. [17] described how contrasting pruning methods affected the yield components of Thompson type raisin grapes, and Espindola et al. [3] published similar data for 'Flame Seedless' grown as raisin grapes on a "parronal" overhead DOV raisin vineyard in Argentina. To our knowledge, DOV raisin yield and quality of Thompson-type raisin grapes on the overhead arbor have not been published in the scientific literature, but such data would be useful for comparative purposes as other possible raisin production systems are considered in California [1], and as other raisin producing countries consider adopting DOV systems in their countries. Therefore, the objective of this work was to determine the potential yield and quality of several Thompson-type raisin grapes subjected to different pruning severities on an overhead arbor trellis. 


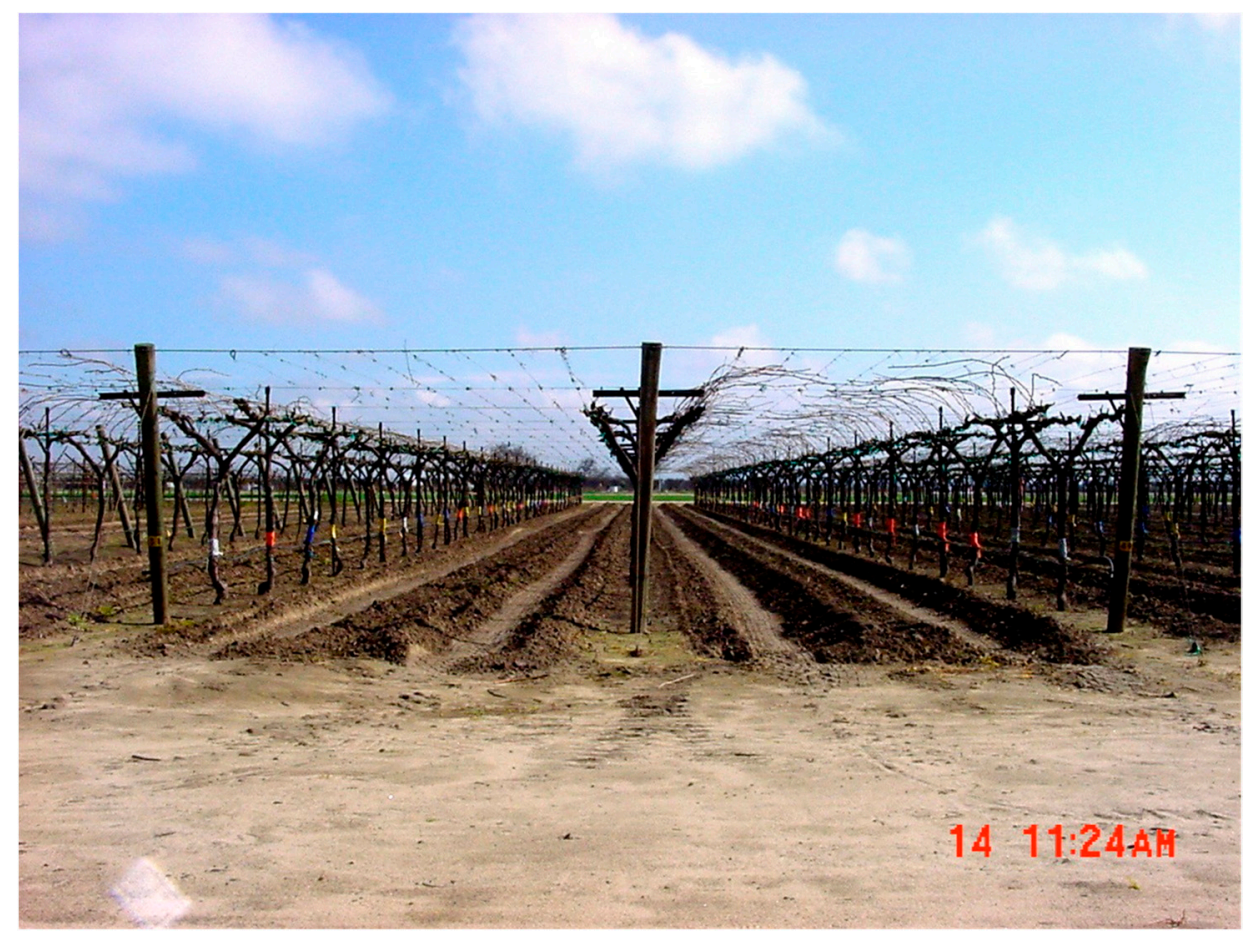

Figure 1. The overhead arbor vineyard used in the trial. The picture was taken after winter pruning and before budbreak to illustrate the arrangement of canes (right of center) and spurs (left of center) on the vine's quadrilateral cordons.

\section{Materials and Methods}

The experiment was conducted in an overhead arbor DOV raisin vineyard at the University of California Kearney Agricultural Research and Extension Center (KAC), Parlier, CA (latitude $36^{\circ} 36^{\prime} 42^{\prime \prime} \mathrm{N}$, longitude $119^{\circ} 31^{\prime} 34^{\prime \prime} \mathrm{W}$, altitude $338 \mathrm{ft}$ ). The vineyard was established in 1996 on Hanford sandy loam soil, having a restrictive feature $>2.0 \mathrm{~m}$ beneath the soil surface [18]. Own-rooted cuttings of four different grapevine (Vitis vinifera L.) varieties: 'Thompson Seedless', 'DOVine', 'Fiesta', and 'Selma Pete' were planted in eastwest rows at a spacing of $1.82 \mathrm{~m}$ within rows, and $3.66 \mathrm{~m}$ between rows. Vines were planted in replicate plots of each variety. Each plot consisted of eighteen vines: six consecutive vines of a given variety down a row, and in each of the two adjacent rows. Replicate plots of similar size and layout were randomly assigned to each of the four varieties in a randomized complete block design replicated six times. Vines were allowed to grow on the ground in 1996 and pruned to two nodes in winter 1996-1997. Vines were trained up stakes in 1997, and quadrilateral cordons established in 1997-1998. The first fruiting year was 1999, and data collection for this trial was initiated in 2001.

The vines were supported by an overhead arbor trellis the design of which has been described previously $[1,12,16]$. Briefly, the trellis has two parallel cordon wires $(0.79-\mathrm{m}$ apart) mounted to crossarms attached to steel stakes at $1.73-\mathrm{m}$ above the soil surface (Figure 1). The stakes extended vertically $0.35-\mathrm{m}$ above the cross arms. The apex of each stake helped support a framework of wires that included seven foliage catch wires running parallel to the vine rows and spaced approximately $0.35-$ to $0.56-\mathrm{m}$ apart. There were also a pair of movable rake wires straddling the center of each vine row that were brought in $(0.43-\mathrm{m}$ apart $)$ each winter, and spread apart $(0.79 \mathrm{~m})$ each spring, to help divide the renewal and fruiting sections of the canopy.

Having the same variety in the same position in each of three consecutive rows accommodated the unique training system employed in overhead arbor DOV raisin vineyards (Figure 1). As stated previously, the canopies of grapevines on overhead arbor DOV trellises are separated into fruiting and renewal sections. Cordons on one side of the vines in each row are cane pruned while cordons on the other side of the vines are spur pruned. Vines 
in adjacent rows are pruned in a coordinated fashion such that trellis wires spanning the spaces between adjacent rows support either fruiting canes or renewal shoots ([1]; Figure 1). Trellis wires holding fruiting canes in one year will support renewal shoots, the following year. Each replicated variety plot was divided into two equal halves, and half of the vines were randomly assigned to one of two dormant pruning treatments: 8 or 6 canes per vine. There were 15 nodes on each cane, so vines pruned to 8 canes per vine retained 120 nodes (on canes) per vine whereas vines pruned to 6 canes had 90 nodes per vine. Canes were left on two cordons per vine opposite similar cordons with fruiting canes in adjacent rows. The remaining two cordons on each vine were spur-pruned, leaving approximately one two-bud spur for each $0.15 \mathrm{~m}$ of cordon length.

In spring, the rake wires in each row were moved apart after the shoots were long enough to overtop them. This helped separate the fruiting and renewal sections of the canopies. In early August of each year, replicated berry samples were collected from vines in each plot following standard methods described previously [13]. Briefly, samples consisted of 100 berries collected from the top, middle, and bottom of 33 clusters selected at random from among the vines in each treatment replicate. The samples were weighed and average berry weight calculated. The berries were then homogenized in a blender, the juice was filtered, and soluble solids were measured with a hand-held temperaturecompensating, digital refractometer (Palette 101; Atago, Farmingdale, NY, USA). Titratable acidity of the juice was determined by titration with $0.133 \mathrm{~N} \mathrm{NaOH}$ to an 8.20 endpoint using an automatic titrator (900A; Orion Research, Boston, MA, USA).

Raisins are best when made from grapes having $>20$ Brix at the onset of drying but if canes are cut too late, they will not dry sufficiently [19]. Therefore, if TSS was $\geq 20$ Brix before the middle of August, the canes were cut. If berries had not achieved 20 Brix by the middle of August, cane severance was delayed until mid-late August if good weather was anticipated. Thus, berry samples and cane severance occurred on different days for different varieties in some years (Table 1). Canes were severed above the third or fourth basal node with pruning shears. Any clusters of fruits on shoots from the basal buds were clipped off the vine and hung from trellis wires in the fruiting zone. After cane severance, grapes were allowed to dry until their moisture levels were judged to be $\leq 16 \%$, or poor drying weather was anticipated, whichever came first. Raisins were then harvested by hand. Harvest dates for different varieties varied and are noted in Table 1.

Table 1. Dates when canes were severed, and raisins harvested, at the University of California Kearney Agricultural Research and Extension Center, Parlier, CA, USA.

\begin{tabular}{|c|c|c|c|c|c|c|}
\hline \multirow{3}{*}{ Cultivar } & \multicolumn{6}{|c|}{ Year } \\
\hline & \multicolumn{2}{|c|}{2001} & \multicolumn{2}{|c|}{2002} & \multicolumn{2}{|c|}{2003} \\
\hline & Canes-Cut & Raisin Harvest & Canes-Cut & Raisin Harvest & Canes-Cut & Raisin Harvest \\
\hline DOVine & 14 August & 11 October & 19 August & 16 October & 14 August & 28 October \\
\hline Fiesta & 14 August & 11 October & 22 August & 22 October & 14 August & 28 October \\
\hline Selma Pete & 14 August & 11 October. & 12 August & 15 October & 14 August & 28 October \\
\hline Thompson Seedless & 14 August & 11 October & 22 August & 22 October & 14 August & 28 October \\
\hline
\end{tabular}

At harvest, whole clusters of raisins were weighed and then raisins were destemmed, and approximately $2 \mathrm{~kg}$ of raisins from each plot were submitted to the USDA processed products division, Fresno, CA, for moisture and quality determination following official methods [20]. Raisins were graded using an airstream sorter and reported as Grade A and B ("B and better"), with $>70 \%$ of well-matured grapes, and substandard grade, with $<55 \%$ of fairly well matured grapes. Yield comparisons were made after adjusting raisin weights to $14 \%$ moisture [8]. Yield per hectare was determined by multiplying the yield per vine $\times$ the number of vines per hectare. Experimental design was a split-plot, with the main plot factor being grapevine variety, replicated six times, and the sub plot factor being 
pruning level (six or eight canes), and statistical analyses were performed using SAS (SAS 9.4, SAS Institute, Cary, NC, USA).

\section{Results and Discussion}

The number of clusters per vine differed in some years, as expected (Table 2). Cluster numbers, particularly those on canes, were particularly high in 2001, and there were fewer clusters on average the following two years. There were relatively minor, but statistically significant, variety $\times$ year interaction effects on cluster numbers (interactions not shown). Grapevine varieties differed with respect to the number of clusters on shoots from renewal cordons, canes, and fruiting cordons (Table 2). 'Thompson Seedless' had the fewest clusters on renewal or fruiting cordons, indicating that it had the lowest basal bud fertility of the varieties tested. 'Fiesta' also had relatively few clusters on cordons, in agreement with previous findings that 'Fiesta' has low basal bud fertility $[9,13,17]$; 'DOVine' and 'Selma Pete' had the most clusters on cordons. 'Fiesta' had the most clusters on canes, followed by 'Selma Pete', 'DOVine', and 'Thompson Seedless', in agreement with another study [19]. 'Fiesta' also produced more clusters than 'Selma Pete' on an open gable trellis [13]. 'Thompson Seedless' is well known for having basal buds of low fertility, and relatively low shoot emergence $[17,21]$. Clusters of grapes on shoots from basal buds are undesirable for DOV because such clusters on fruiting cordons are often below the point of cane severance and will not DOV, and the renewal shoots cannot be cut since they are to be the fruiting canes the following year. Clusters on renewal shoots can be easily removed before bloom, or allowed to form fruit and the fruit harvested for raisins (which requires offsite drying due to canopy cover), juice, or wine, depending on the anticipated value of the fruit versus the cost of labor and transportation.

Table 2. The effect of year, grapevine variety, and the number of canes, on the number of clusters on shoots from the renewal cordons, fruiting canes, and fruiting cordons of grapevines grown on an overhead arbor trellis system at the University of California Kearney Agricultural Research and Extension Center, Parlier, CA, USA.

\begin{tabular}{lccc}
\hline \multirow{2}{*}{ Factor } & \multicolumn{3}{c}{ Clusters (No./Vine) } \\
\cline { 2 - 4 } & & Canes & Fruiting Cordon \\
\hline Year & $23 \mathrm{a} \mathrm{z}^{\mathrm{z}}$ & $90 \mathrm{a}$ & $17 \mathrm{a}$ \\
2001 & $16 \mathrm{~b}$ & $60 \mathrm{~b}$ & $18 \mathrm{a}$ \\
2002 & $13 \mathrm{c}$ & $58 \mathrm{~b}$ & $11 \mathrm{~b}$ \\
2003 & & & \\
Variety & $22 \mathrm{a}$ & $61 \mathrm{c}$ & $19 \mathrm{a}$ \\
DOVine & $16 \mathrm{~b}$ & $91 \mathrm{a}$ & $13 \mathrm{~b}$ \\
Fiesta & $21 \mathrm{a}$ & $72 \mathrm{~b}$ & $19 \mathrm{a}$ \\
Selma Pete & $10 \mathrm{c}$ & $53 \mathrm{~d}$ & $9 \mathrm{c}$ \\
Thompson Seedless & & & \\
Number of canes & 16 & $62 \mathrm{~b}$ & 15 \\
Six & 18 & $76 \mathrm{a}$ & 15 \\
Eight & & & \\
Significance & $<0.01$ & $<0.01$ & $<0.01$ \\
Year & $<0.01$ & $<0.01$ & $<0.01$ \\
Variety & 0.02 & $<0.01$ & $<0.01$ \\
Year $\times$ variety & 0.20 & $<0.01$ & 0.67 \\
Number of canes & 0.43 & 0.32 & 0.07 \\
Year $\times$ Number of canes & 0.99 & 0.30 & 0.08 \\
Variety $\times$ number of canes & 0.68 & 0.25 & 0.78 \\
Year $\times$ variety $\times$ number of canes & & & \\
\hline
\end{tabular}

${ }_{\bar{z}}$ Values are means. Means followed by a different letter are significantly different according to Duncan's New Multiple Range Test, $p<0.05$.

The number of canes per vine did not affect the number of clusters on cordons, nor were there any interaction effects between the number of canes per vine and any other 
factors with respect to the number of clusters on cordons. 'Fiesta' produced the most clusters on canes, followed by 'Selma Pete', 'DOVine,' and 'Thompson Seedless' (Table 2). Vines with eight canes had about 33\% more nodes than vines with six canes, but only $22 \%$ more clusters, regardless of year or grapevine variety (Table 2). These results agree with a different study with the same grapevine varieties, where vines with longer canes had lower budbreak and fewer clusters per node than vines with shorter canes [19], which might help explain why the number of clusters did not increase proportionately with the number of canes and nodes.

There were seasonal effects on berry weight, composition, and raisin yield and quality (Table 3). As in the case of cluster counts, there were some year $\times$ variety interactions with respect to berry and raisin data (interaction effects not shown), but no other factors interacted to affect those variables except for titratable acidity (TA). Therefore, only main effects are shown, as with cluster counts. 'Selma Pete' had the largest berries, followed by 'Fiesta', 'DOVine', and 'Thompson Seedless' (Table 3). 'Selma Pete' also had the highest TSS, followed by DOVine, 'Thompson Seedless', and Fiesta. Further, 'Selma Pete' had the highest TA, followed by 'Thompson Seedless', 'Fiesta', and 'DOVine'. These data agree with the results of other studies, showing 'Selma Pete' has heavier berries, ripens sooner (develops higher TSS sooner), and has higher TA [19] than other Thompson type grapes [13].

Table 3. The effect of grapevine variety and the number of canes on berry weight, soluble solids, titratable acidity (TA), and on raisin field moisture, yield, and quality grades. Vines were trained to quadrilateral cordons, and cane pruned, with 15 nodes per cane, at the University of California Kearney Agricultural Research and Extension Center, Parlier, CA, USA 2001-2003.

\begin{tabular}{|c|c|c|c|c|c|c|c|}
\hline \multirow{4}{*}{ Factor } & \multicolumn{3}{|c|}{ Berry } & \multicolumn{4}{|c|}{ Raisin } \\
\hline & \multirow{3}{*}{$\begin{array}{c}\text { Fresh wt. } \\
\left(\mathrm{g} \bullet \text { berry }^{-1}\right)\end{array}$} & \multirow{3}{*}{$\begin{array}{c}\begin{array}{c}\text { Soluble } \\
\text { Solids }\end{array} \\
\text { ( }{ }^{\circ} \text { Brix) }\end{array}$} & \multirow{3}{*}{$\begin{array}{l}\text { TA } \\
(\%)\end{array}$} & \multirow{3}{*}{$\begin{array}{c}\begin{array}{c}\text { Field } \\
\text { Moisture }\end{array} \\
(\%)\end{array}$} & \multirow{3}{*}{$\begin{array}{c}\text { Yield } \\
\left(\mathrm{Mg} \bullet \mathrm{ha}^{-1}\right)^{\mathrm{y}}\end{array}$} & \multicolumn{2}{|c|}{ Grade } \\
\hline & & & & & & Substandard & $\begin{array}{c}\text { "B" and } \\
\text { Better }\end{array}$ \\
\hline & & & & & & $(\%)$ & $(\%)$ \\
\hline \multicolumn{8}{|l|}{ Year } \\
\hline 2001 & $2.13 \mathrm{a}^{\mathrm{z}}$ & $20.6 \mathrm{a}$ & $0.49 \mathrm{a}$ & $17 \mathrm{~b}$ & $11.05 \mathrm{~b}$ & 3 & $81 \mathrm{a}$ \\
\hline 2002 & $2.13 \mathrm{a}$ & $19.8 \mathrm{~b}$ & $0.46 \mathrm{~b}$ & $14 \mathrm{c}$ & $12.66 \mathrm{a}$ & 3 & $81 \mathrm{a}$ \\
\hline 2003 & $1.87 \mathrm{~b}$ & $19.8 \mathrm{~b}$ & $0.50 \mathrm{a}$ & $19 \mathrm{a}$ & $7.71 \mathrm{c}$ & 3 & $72 \mathrm{~b}$ \\
\hline \multicolumn{8}{|l|}{ Variety } \\
\hline DOVine & $1.95 \mathrm{c}$ & $20.5 \mathrm{~b}$ & $0.36 \mathrm{~d}$ & $16.2 \mathrm{c}$ & $9.86 \mathrm{bc}$ & $2.6 \mathrm{bc}$ & $79 \mathrm{~b}$ \\
\hline Fiesta & $2.06 \mathrm{~b}$ & $18.8 \mathrm{c}$ & $0.47 \mathrm{c}$ & $17.2 \mathrm{~b}$ & $12.24 \mathrm{a}$ & $3.2 \mathrm{~b}$ & $73 c$ \\
\hline Selma Pete & $2.35 \mathrm{a}$ & $21.8 \mathrm{a}$ & $0.57 \mathrm{a}$ & $15.3 \mathrm{~d}$ & $10.27 \mathrm{~b}$ & $2.1 \mathrm{c}$ & $90 \mathrm{a}$ \\
\hline Thompson Seedless & $1.82 \mathrm{~d}$ & $19.1 \mathrm{c}$ & $0.54 \mathrm{~b}$ & $18.0 \mathrm{a}$ & $9.53 c$ & $4.1 \mathrm{a}$ & $72 \mathrm{c}$ \\
\hline \multicolumn{8}{|l|}{ Number of canes } \\
\hline Six & 2.03 & 20.1 & $0.49 \mathrm{a}$ & 17 & $9.98 \mathrm{~b}$ & 3 & 78 \\
\hline Eight & 2.05 & 20.0 & $0.48 \mathrm{~b}$ & 17 & $10.98 \mathrm{a}$ & 3 & 78 \\
\hline \multicolumn{8}{|l|}{ Significance } \\
\hline Year & $<0.01$ & $<0.01$ & $<0.01$ & $<0.01$ & $<0.01$ & 0.17 & $<0.01$ \\
\hline Variety & $<0.01$ & $<0.01$ & $<0.01$ & $<0.01$ & $<0.01$ & $<0.17$ & $<0.01$ \\
\hline Year $\times$ variety & $<0.01$ & $<0.01$ & $<0.01$ & $<0.01$ & 0.11 & $<0.01$ & $<0.01$ \\
\hline Number of canes & 0.42 & 0.15 & 0.01 & 0.99 & $<0.01$ & 0.83 & 0.63 \\
\hline Year $\times$ number of canes & 0.51 & 0.62 & $<0.01$ & 0.77 & 0.04 & 0.42 & 0.64 \\
\hline Variety $\times$ number of canes & 0.18 & 0.13 & $<0.01$ & 0.48 & 0.42 & 0.65 & 0.11 \\
\hline Year $\times$ variety $\times$ number of canes & 0.33 & 0.51 & $<0.01$ & 0.15 & 0.63 & 0.33 & 0.21 \\
\hline
\end{tabular}

${ }^{\mathrm{z}}$ Values are means. Means followed by a different letter are significantly different according to Duncan's New Multiple Range Test, $p<0.05$.

$\mathrm{y}$ Yield is based on raisin weights standardized to $14 \%$ moisture.

'Selma Pete' raisins had the lowest field moisture at harvest, followed by 'DOVine', 'Fiesta', and 'Thompson Seedless' (Table 3). Field moisture data demonstrate the importance of early maturity in producing natural DOV raisins [13,19]. Packing houses in the USA require raisins to be delivered at $<16 \%$ moisture [1], and 'Selma Pete' and (marginally) 'DOVine', the earliest ripening varieties, were the only ones to achieve an acceptable moisture level on average. Fiesta was the most productive (had the highest raisin yield), 
followed by 'Selma Pete' and 'DOVine', and then 'Thompson Seedless'. The higher productivity of 'Fiesta' is likely the reason why it ripens later, as the fruit on under-cropped 'Fiesta' vines may ripen sooner than the fruit from 'Selma Pete' having a normal crop [19]. 'Thompson Seedless' had the most substandard raisins, followed by 'Fiesta' and 'DOVine', with 'Selma Pete' having the fewest substandard raisins. 'Selma Pete' had the most "B and better" raisins, the highest grade, followed by 'DOVine', whereas 'Fiesta' and 'Thompson Seedless' had the lowest percent "B and better." Overall, 'Thompson Seedless' performed poorly, ripening and drying too late, and having raisins of lower quality.

The number of canes per vine did not affect the berry quality variables measured except for TA (Table 3), and the number of canes did not interact with other factors to affect any other berry or raisin variables except yield, in which case there were minor interactions between the year and the number of canes (interaction not shown). Increasing the number of canes from six to eight increased yield by $10 \%$, regardless of the variety (Table 3). As previously stated, increasing the number of nodes by $33 \%$ increased cluster counts by $22 \%$, but only increased yields by $10 \%$, probably due to the fact that leaving more nodes after pruning generally reduces the number of shoots and clusters per node and average cluster weight [17]. Even so, the additional nodes were helpful as they modestly increased yield without reducing quality. The raisin yields in this study were similar to those reported for the open gable trellis [13]. Average 'Fiesta' yield in this study was approximately $11 \%$ more than on an open gable, whereas 'DOVine' yield was approximately $11 \%$ lower on the overhead than on the open gable. 'Selma Pete' yields were about the same on either trellis. However, the average yields by variety in this study include data from an equal number of vines that were pruned to six or eight canes per vine, and leaving additional canes increased yield approximately $10 \%$ regardless of variety.

In conclusion, the grapevine varieties tested have the potential for similar or greater yields on the overhead arbor compared to the open gable. However, 'DOVine' has not been widely planted [2], and most commercial DOV raisin vineyards have 'Fiesta' or 'Selma Pete' on an overhead arbor [22]. Our data generally validate these decisions, since 'Fiesta' is the most productive variety on the overhead arbor, whereas 'Selma Pete' produces the highest quality raisins, which can be depended on to dry adequately each year. These data will serve as a useful reference as new raisin grape varieties are introduced, and other raisin production systems are considered. The feasibility of new raisin production systems will depend on their performance relative to the system described in this manuscript.

Funding: This research was funded by the California Raisin Marketing Board.

Data Availability Statement: The raw data supporting the conclusions of this article will be made available without undue researvation.

Acknowledgments: This work was initiated by L.P. Christensen (deceased), who transferred responsibility to M.W. Fidelibus in 2002. The helpful assistance of Donald Katayama, Jorge Osorio-Aguilar, and Stephen J. Vasquez is gratefully acknowledged.

Conflicts of Interest: The author declares no conflict of interest.

\section{References}

1. Fidelibus, M.W. Grapevine cultivars, trellis systems, and mechanization of the California raisin industry. HortTechnology 2014, 24, 285-289. [CrossRef]

2. California Department of Food and Agriculture and U.S. Department of Agriculture. California Department of Food and Agriculture and U.S. Department of Agriculture California Grape Acreage Report, 2020 Crop; California Department of Food and Agriculture and U.S. Department of Agriculture: Sacramento, CA, USA, 2021.

3. Espindola, R.S.; Camargo, J.A.; Pringles, E.; Battistella, M. Effect of pruning severity on yield, drying time, and wages in Flame Seedless dry-on-vine and traditional raisin productions systems in Argentina. South Africa J. Enol. Vitic. 2017, 39, 21-26. [CrossRef]

4. Calvin, L.; Martin, P. Labor-intensive U.S. fruit and vegetable industry competes in a global market. Amber Waves 2010, 8, 24-32.

5. Charlton, J.; Taylor, E.; Vougioukas, S.; Rutledge, Z. Innovations for a shrinking agricultural workforce. Choices 2019, $34,1-8$.

6. May, P.; Kerridge, G.H. Harvest pruning of Sultana vines. Vitis 1967, 6, 390-393.

7. Clingeleffer, P.R. Sultana raisin production. In A Treatise on Raisin Production, Processing, and Marketing; Petrucci, V.E., Clary, C.D., Eds.; Malcolm Media Press: Clovis, CA, USA, 2002; pp. 133-144. 
8. Fidelibus, M.W.; Vasquez, S.J.; Cathline, K.A. Canopy separation and defoliation do not improve the dry-on-vine (DOV) raisin making method for 'Thompson Seedless' grapevines on traditional trellises. J. Amer. Pomol. Soc. 2007, 61, 61-70.

9. Weinberger, J.H.; Loomis, N.H. 1974 'Fiesta' grape. HortScience 1974, 9, 603.

10. Christensen, L.P. (Ed.) Raisin grape varieties. In Raisin Production Manual; University of California Division of Agriculture and Natural Resources: Oakland, CA, USA, 2000; pp. 38-47.

11. Okie, W.R. Register of new fruit and nut varieties, List 41. HortScience 2002, 37, 251-272. [CrossRef]

12. Christensen, L.P. (Ed.) Current developments in harvest mechanization and DOV. In Raisin Production Manual; University of California Division of Agriculture and Natural Resources: Oakland, CA, USA, 2000; pp. 252-263.

13. Fidelibus, M.W.; Christensen, L.P.; Katayama, D.G.; Ramming, D.W. Early-ripening grapevine cultivars for dry-on-vine raisins on an open gable trellis. HortTechnology 2008, 18, 740-745. [CrossRef]

14. Fidelibus, M.W. Canopy Separation Did Not Improve Dry-on-Vine Raisin Yield or Quality from Selma Pete Grapevines on Open Gable Trellises. Catalyst Disc. Prac. 2017, 1, 73-79. [CrossRef]

15. da Costa, T.V.; Scarpare Filho, J.A.; Fidelibus, M.W. Ethephon with 1-aminocyclopropane-1-carboxylic acid can defoliate grapevines, and thereby improve vine-drying of grapes. HortTechnology 2015, 25, 363-369. [CrossRef]

16. Williams, L.E.; Fidelibus, M.W. Measured and estimated water use and crop coefficients of grapevines trained to overhead trellis systems in California's San Joaquin Valley. Irrigation. Sci. 2016, 34, 431-441. [CrossRef]

17. Cathline, K.A.; Zhuang, G.; Fidelibus, M.W. Productivity and fruit composition of dry-on-vine raisin grapes pruned to 15- or 20-node canes on an overhead trellis. Catalyst Discov. Prac. 2020. [CrossRef]

18. U.S. Department of Agriculture Natural Resources Conservation Service Web Soil Survey. Available online: https: / websoilsurvey. sc.egov.usda.gov / App/HomePage.htm (accessed on 24 January 2008).

19. Parpinello, G.P.; Heymann, H.; Vasquez, S.; Cathline, K.A.; Fidelibus, M. Grape Maturity, Yield, Quality, Sensory Properties, and Consumer Acceptance of Fiesta and Selma Pete Dry-on-Vine Raisins. Am. J. Enol. Vitic. 2012, 63, 212-219. [CrossRef]

20. U.S. Department of Agriculture. United States Standards for Grades of Processed Raisins. USDA: Washington, DC, USA, 2016; $15 p$.

21. Christensen, L.P. Fruitfulness and yield characteristics of primary and lateral canes of 'Thompson Seedless' grapevines. Am. J. Enol. Vitic. 1985, 37, 39-43.

22. US Department of Agriculture-National Agricultural Statistics Service and California Department of Food and Agriculture. 2020 California Raisin Grape Mechanical Harvest Report; California Department of Food and Agriculture and U.S. Department of Agriculture: Sacramento, CA, USA, 2021;2p. 